\title{
Evaluating Chemical Risks: Results of a Survey of the British Toxicology Society
}

Paul Slovic, Torbjörn Malmfors, C. K. Mertz, Nancy Neil, and lain F. H. Purchase

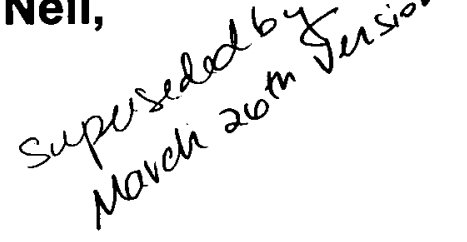

Address correspondence to:

Paul Slovic

Decision Research

1201 Oak St.

Eugene, OR 97401 USA

phone: $541-485-2400$

fax: 541-485-2403

December 13, 1996 


\section{Summary}

1 Members of the British Toxicology Society participated in a survey to determine their attitudes, beliefs, and perceptions regarding risks from chemicals. Similar surveys had previously been conducted with toxicologists and members of the general public in the United States and Canada. Data from 312 completed questionnaires were analyzed.

2 In general, the British toxicologists judged risks to be quite low for most hazards, with the exception of cigarette smoking and asbestos. They tended to have quite favorable attitudes toward the use of chemicals and were confident about the adequacy of chemical regulations.

3 As in previous studies of toxicologists, women expressed higher perceptions of risk than did men and had consistently stronger anti-chemical attitudes.

4 Toxicologists working in industry had more favorable attitudes towards chemicals and their use than did those working in academic settings.

5 When asked to evaluate technical summaries of various animal studies there was considerable disagreement among the respondents about the toxicity of the chemicals involved.

6 In general, British toxicologists were equivocal about the reliability of animal studies in predicting human effects (particularly carcinogenicity) but were rather confident that human risks could be assessed accurately.

Key words: risk assessment; risk attitudes; risk perception; British Toxicology Society 


\section{Introduction}

Judgments of chemical risks have been the subject of systemic examination in a series of studies dating back to 1988 . Kraus, Malmfors, and Slovic ${ }^{1}$ surveyed members of the U.S. Society of Toxicology and members of the general public to determine their attitudes, beliefs, and perceptions regarding risks from chemicals. That survey was replicated and extended in Canada in 1993, with members of the Canadian Society of Toxicology and a large representative sample of the Canadian public. A similar survey was sent to the entire membership of the British Toxicology Society in 1994 and the results are reported in this paper.

The original study by Kraus et al. was motivated by the premise that different assumptions, conceptions, and values underlie much of the discrepancy between expert and lay views of chemical risks. They attempted to address this issue by exploring the cognitive models, assumptions, and inference methods that comprise laypeople's 'intuitive toxicological theories' and by comparing these theories with the cognitive models, assumptions, and inference methods of scientists working in the field of toxicology.

Toxicologists and laypeople were found to differ greatly, documenting some common assumptions (e.g., that the public believes natural chemicals to be safer than synthetic ones) and verifying many of the other hypotheses that motivated the questionnaire. Of particular importance was the finding that the members of the public were much less sensitive than the toxicologists to considerations of dose and exposure. Lay respondents generally tended to view chemicals as either safe or dangerous, and they appeared to equate even small exposures to toxic or carcinogenic chemicals with almost certain harm. This tendency was found to be associated with high levels of concern about very small residues of chemicals on food and with a desire to reduce chemical risks regardless of cost. Although Kraus et al. were not able to develop a precise 
description of the lay mental models of how a chemical carcinogen works, their results were consistent with a contagion or contamination model, ${ }^{2}$ which is very different from the kinds of models that toxicologists hold.

One of the major surprises in the data was the lack of difference between the public and toxicologists with regard to their confidence in extrapolation from animal studies. Both groups were divided in their opinions, and the high percentage of toxicologists who lacked confidence in animal studies is particularly noteworthy in light of the extensive reliance on such studies in risk management. Also, whereas the public's trust in extrapolation from animal studies increased greatly when these studies were found to produce evidence of carcinogenicity, toxicologists were much less confident that such evidence could be used to predict cancer risk in humans. Kraus et al. also found an affiliation effect; toxicologists working for industry saw chemicals as more benign than did their counterparts in academia and government.

The studies of toxicologists and laypeople in Canada ${ }^{3-5}$ replicated and extended the results obtained in the United States. Canadian toxicologists had far lower perceptions of risk for all hazards and more favorable attitudes toward chemicals than did the Canadian public. The public's attitudes toward chemicals were quite negative and showed the same lack of doseresponse sensitivity found in the U.S. study. Both the public and the toxicologists exhibited a lack of confidence in the value of animal studies for predicting human health risks. An important result, also found in the U.S. survey, was that a study showing evidence that a chemical caused cancer in animals led to high confidence within the public that the chemical would cause cancer in humans but did not elicit much confidence among the toxicologists. Affiliation effects found in the U.S. survey were also replicated in the Canadian survey of toxicologists. 
A special feature of the Canadian research was the inclusion of technical material for the toxicologists to evaluate and the inclusion of questions pertaining to general philosophical attitudes known as worldviews. ${ }^{6}$ The range of disagreement among toxicologists on some of the technical questions was significant as was the correlation between technical judgments and some 'nonscientific' factors such as gender and worldviews. Also important was the lack of agreement that animal studies of the type done in the National Toxicology Program in the U.S. will permit reliable judgments of a chemical's carcinogenic potential in humans. 


\section{Methods}

\section{Survey content}

The present survey was designed to assess many different aspects of health-risk assessment. Accordingly, a variety of question types and formats were used, including ratings of perceived risk, attitude and opinion questions, and questions pertaining to the technical evaluation of several chemicals. The survey design was similar but not identical to the previous survey conducted by the authors with the Canadian Society of Toxicologists in 1993. ${ }^{5}$ The main components of the survey are outlined below.

Risk perception. In the first segment of the survey, respondents were asked to indicate the degree of health risk they associated with each of 29 items covering a wide range of hazards, including risks from technology (e.g., nuclear power, electric and magnetic fields), lifestyle (e.g., cigarette smoking, alcoholic beverages), pollution (e.g., waste incinerators, indoor air pollution), common substances (e.g., food additives, tap water), and crime and violent behavior. The array of items was selected to include many of the hazards that have recently been of concern to the public, the medical community, or government agencies.

Each of these items was rated in terms of the health risk posed to 'the average exposed citizen of your country.' The possible responses were 'almost no health risk,' 'slight health risk,' 'moderate health risk,' and high health risk.' These responses were coded 1, 2, 3, and 4, respectively, and were then averaged across the 29 items to create a 'risk-perception index' for each respondent.

Attitudes and opinions. The next segment of the survey contained 40 items designed to elicit the respondents' attitudes and opinions regarding a variety of health-risk perception issues. 
These items were presented as statements with which the respondent was asked to agree or disagree. The content of these items included statements about:

- One's local environment (e.g., 'There are serious environmental health problems where I live')

- Government regulation (e.g., 'Chemical risks are sufficiently regulated in this country.')

- Risk/benefit tradeoffs (e.g., 'People should be prepared to accept some risks to their health in order to strengthen the economy.')

- The objectivity of scientific inquiry (e.g., 'When emotions influence scientific judgments, rationality suffers.')

- Health risks from chemicals (e.g., 'In general, the use of chemicals has improved our health more than it has harmed it.')

- Risks from chemicals and radiation

The questions about the risks from chemicals and radiation were designed to assess (a) sensitivity to dose or amount of exposure as a determiner of risk, and (b) opinions about the value of animal tests as predictors of the effects of chemicals on humans.

Worldviews. Over the past decade, evidence has been accumulating regarding the importance of general dispositions or 'worldviews' in determining an individual's perceptions of risk. ${ }^{6-7}$ Most of this evidence comes from studies of the general population. To determine whether worldviews influence the judgments of our toxicologist respondents, the survey contained a small number of statements designed to determine agreement or disagreement with the following worldviews: 
- Fatalism (e.g., 'I feel that I have very little control over risks to my health.')

- Hierarchy (e.g., 'Decisions about health risks should be left to the experts.')

- Individualism (e.g., 'In a fair system, people with more ability should earn more.')

- Egalitarianism (e.g., 'If people in this country were treated more equally, we would have fewer problems.')

- Technological enthusiasm (e.g., 'A high technology society is important for improving our health and social well-being.')

- Economic growth ('Continued economic growth is necessary to improve our quality of life.')

- Consent ('When a risk is very small, it is okay for society to impose that risk on individuals without their consent.')

Toxicological evaluations. Two series of questions were directed toward technical judgments of specific chemicals. In the first series, a table was presented summarizing the 2-year study of Bromoethane done in the U.S. within the National Toxicology Program (NTP). The standard NTP protocol had been used, in which four separate studies were conducted, one each with male mice, female mice, male rats, and female rats. The summary of results from these four studies was presented in the survey in the format shown in Table 1. Bromoethane is an alkylating agent used primarily as a chemical intermediate in various organic syntheses. The chemical was identified only as 'Chemical B'. in the survey. Respondents were asked to study the summary table and to judge the level of carcinogenic activity of Chemical B for male rats, female rats, and so on according to the NTP criteria, which were also defined and displayed in the survey. The NTP categories were: clear evidence of carcinogenic activity, some evidence, equivocal 
evidence, no evidence, and inadequate evidence. Respondents were also asked whether they agreed or disagreed that 'In general animal studies of the type done with Chemical B will permit one to make reliable judgments of the likelihood that the chemical is carcinogenic in humans' and 'Based on the data presented above (in the table), a concentration of $1 \mathrm{ppb}$ of Chemical B in indoor air is acceptable.' Finally, they were asked to indicate whether Chemical B is:

- a probable carcinogen in humans,

- a possible carcinogen in humans,

- probably not carcinogen in humans,

- definitely not carcinogenic in humans, or

- the data are not adequate to make this type of judgment.

Insert Table 1 about here

Next respondents were shown the following paragraph describing results of studies done on the chemical 2-mercaptobenzothiazole, labeled in the survey as 'Compound E.'

$E$ is used as a rubber accelerant and a preservative. The annual production is several million kilograms. It is a solid material with a disagreeable odor. It is insoluble in water but soluble in different solvents. It occurs as a contamination in medicinal products and in rubber baby bottle nipples. It inhibits dopamine-B-hydroxylase.

$\mathrm{E}$ has a low acute toxicity ( $\mathrm{LD}_{50}$ in rats is $2-3 \mathrm{~g} / \mathrm{kg}$ given orally). At repeated oral administration hepatomegaly and forestomach lesions are found in rats at doses around $500 \mathrm{mg} / \mathrm{kg}$. A reproductive toxicity study did not show any toxic effects at $200 \mathrm{mg} / \mathrm{kg}$ given intraperitoneal day 1-15 gestation including embryotoxicity, which was indicated in another study. Genotoxic effects were found in mammalian cells but not in bacteria.

Carcinogenicity studies were evaluated as showing some evidence of carcinogenic activity in rats-mononuclear cell leukemia, pancreatic acinar cell adenomas, adrenal gland pheochromocytomas, and pituitary gland adenomas in females. In mice there was no evidence in males and equivocal evidence in females-hepatocellular adenomas or carcinomas-at $750 \mathrm{mg} / \mathrm{kg}$ given by gavage.

$\mathrm{E}$ has been shown to be a very strong allergen in guinea pigs but is judged a moderate contact sensitizer in humans. 
Respondents were asked to judge the relative toxicity of Chemical $\mathrm{E}$, the risk of using it as a rubber accelerant and preservative, the factors they took into account in assessing its toxicity, and the acceptability of using it in rubber nipples for baby bottles.

Chemical B and Compound $\mathrm{E}$ were selected because the animal data raised a number of questions that made the interpretations and evaluations 'nonobvious.'

Personal characteristics and professional experience. The final section of the survey elicited information pertaining to the personal and professional background of the respondent. In addition to standard demographic information (gender, age, and education), respondents were asked detailed questions pertaining to their organizational affiliation, their experience with various types of chemicals, and the nature of their work, including experience with various specified aspects of risk assessment.

\section{Administration of the survey}

The survey was mailed to all 857 members of the British Society of Toxicology in January, 1994. There were 312 completed surveys returned for a response rate of $36.4 \%$. 


\section{Results}

\section{Background characteristics}

Sixty percent of the toxicologists who completed the survey were age 44 or younger; $66.7 \%$ were male; $53.2 \%$ had a Ph.D. or M.D. degree; toxicology or pharmacology was the most common academic background (45.0\%) followed by biochemistry/chemistry (23.0\%) and biology $(17.1 \%) ; 37.1 \%$ were primarily affiliated with private industry; $26.4 \%$ were primarily with academic institutions; and $17.0 \%$ were primarily with a government agency. Their main current position varied among active scientific research (44.1\%), administrative and/or managerial (32.3\%) and teaching (8.9\%). Nearly half (47.7\%) indicated that general toxicology was their primary field. In terms of primary experience, $51.6 \%$ had worked frequently with drugs; $37.5 \%$ had worked frequently with experimental toxicants; $35.3 \%$ had worked frequently with chemical products such as industrial or household chemicals, food additives and/or cosmetics; and $19.2 \%$ had worked frequently with naturally occurring chemicals. Whereas $60.9 \%$ engaged frequently in toxicological evaluation, $54.8 \%$ frequently engaged in research, and $30.8 \%$ and $30.1 \%$ frequently did testing and risk assessment, respectively. The major test system for these people was animal studies (65.4\% frequently worked with these systems) compared to $33.7 \%$ who worked frequently with in vitro systems and $13.5 \%$ who worked frequently with humans. The survey respondents were highly experienced; $51.3 \%$ had more than 10 years' experience in experimental work and $44.9 \%$ had similar length of experience in evaluation of chemicals, including risk assessment. 


\section{Ratings of risk}

Figure 1 presents the response distributions for the toxicologists' judgments of health risks to the average exposed citizen of their country. Cigarette smoking and asbestos had by far the highest ratings of risk with $79.8 \%$ and $50.3 \%$ high-risk responses, respectively. Dioxins and nuclear waste were rated next highest with $20.2 \%$ and $15.7 \%$ high-risk responses. Other risks that had over $10 \%$ high-risk responses were motor vehicle traffic, suntanning, and crime and violence, all lifestyle or behavioral risks. The remaining items, including most of the chemical hazards, were rated rather low in risk. Three items, mercury in dental fillings, food additives, and tap water, received no high-risk ratings.

\section{Insert Figure 1 about here}

Figure 2 presents the difference in proportion of moderate and high risk ratings between men and women toxicologists. For 27 of the 29 items, women were more likely than men to label an item moderate or high in risk. There was only one item (burning fossil fuels) for which men had slightly more moderate or high-risk responses than women. There were no gender differences for chemical pollution in the workplace. The 'gender gap' was particularly large for nuclear waste and nuclear power reactors, followed by outdoor air pollution, alcoholic beverages, suntanning, and environmental tobacco smoke.

Insert Figure 2 about here

\section{Attitudes and opinions}

Tables 2 to 10 present the response distributions for the 49 attitude and opinion statements. These statements are grouped together by content category for easier interpretation. 
Category 1 (Table 2) includes general statements about risks from chemicals. An overwhelming majority of toxicologists (93.2\%) agreed that the use of chemicals has improved our health more than it has harmed it (Statement 1a). A strong majority disagreed $(78.8 \%)$ that they try hard to avoid contact with chemicals and chemical products in their daily life. One third of the toxicologists agreed that our society has perceived only the tip of the iceberg with regard to the risks associated with chemicals (Statement 1c). However, only $22.4 \%$ agreed that it can never be too expensive to reduce the risks associated with chemicals (Statement 1d).

Insert Table 2 about here

Category 2 (Table 3) included 11 questions designed to gauge one's trust in the use of animal and epidemiological studies to determine a chemical's risk to humans. Only about half of the toxicologists agreed with the general Statement 2a, 'The way that an animal reacts to a chemical is a reliable predictor of how a human would react to it.' Moreover, when an animal study was said to provide 'evidence that a chemical causes cancer in animals' (Statement 2b), agreement that it 'will cause cancer in humans' decreased to $34.9 \%$. When asked whether 'laboratory studies of a chemical's harmful effects on animals allow scientists to accurately determine how much of the chemical it takes to cause similar harm in humans,' agreement decreased to $29.8 \%$ (Statement $2 \mathrm{c}$ ).

Insert Table 3 about here

A series of five statements (Statements $2 \mathrm{~d}$ to $2 \mathrm{~h}$ ) explored attitudes about the accuracy of risk assessment in carcinogenicity studies in animals. A strong majority of toxicologists (85.5\%) agreed that carcinogenicity studies in animals 'overestimate risks to humans because some 
animal studies produce carcinogenic effects due to cytotoxic or other effects that occur only at high doses.' Over three-quarters (77.9\%) also agreed that such studies 'overestimate risks to humans because human exposures are quite small compared to the levels of exposures to animals in these studies' (Statement 2f). However, the respondents were divided over whether risks to humans were overestimated 'due to the use of animals that are extremely sensitive (cancer prone)'; $49.7 \%$ agreed, $42.3 \%$ disagreed and $8.0 \%$ were undecided. Half $(51.6 \%)$ of the toxicologists disagreed that animal studies underestimated risks to humans 'because there is greater genetic diversity in the human population than there is in laboratory animals' (Statement 2g); $15.1 \%$ were undecided. Respondents were divided about whether animal studies 'underestimate risks to humans due to synergistic effects among the many substances that humans are exposed to' (Statement $2 \mathrm{~h}$ ); $40.7 \%$ agreed, $38.5 \%$ disagreed, and $20.8 \%$ were undecided.

Three additional questions examined opinions about cancer risk-assessment models and epidemiological studies (Statements $2 \mathrm{i}$ to $2 \mathrm{k}$ ). A strong majority $(71.2 \%)$ indicated that riskassessment models tend to overestimate risk when extrapolating laboratory data from high to low doses. Seventy percent also indicated that such models overestimate risks when extrapolating data from animals to humans. About $60 \%$ thought that epidemiological studies tended to overestimate cancer risks from chemicals. In general, toxicologists tended to believe that animal and epidemiological studies overestimate the risks that chemicals pose to humans.

Attitudes toward regulation of chemical hazards are indicated by responses to two statements in Category 3 (Table 4). Fairly strong confidence in the regulatory system is shown by $63.5 \%$ of respondents who agreed that 'Chemical risks are sufficiently regulated in this 
country' (Statement 3a). However, less support for regulatory intervention into individual behaviors was shown by the tendency to agree (57.4\%) with Statement $3 b$ that the government has no right to regulate people's personal risk-taking.

Insert Table 4 about here

Statements $4 \mathrm{a}$ and $4 \mathrm{~b}$ (Table 5) assessed the respondents' sensitivity to the relationship between dose or amount of exposure to a chemical and the degree of health risk. Whereas the public tends to equate any degree of exposure with harm, 'toxicologists tend to view things quite differently; $90.7 \%$ of the toxicologists disagreed that exposure to a chemical that can cause cancer implies that the exposed person will probably get cancer some day (Statement 4a). A high proportion (63.4\%) also disagreed with Statement $4 \mathrm{~b}$ asserting that 'if a carcinogen were found in my tap water at levels below regulatory concern, I wouldn't drink the water.' Interestingly, $27.5 \%$ agreed with this statement.

Insert Table 5 about here

Views regarding threshold doses for genotoxic and nongenotoxic carcinogens were explored in Statements $4 \mathrm{c}$ and $4 \mathrm{~d}$ (Table 5). About one-third (32.3\%) of the toxicologists agreed that there was a threshold dose for genotoxic carcinogens, below which they do not induce neoplasms, whereas $76.0 \%$ agreed that there was a threshold dose for nongenotoxic carcinogens.

Four additional statements about cancer are grouped in Category 5 (Table 6). Most toxicologists (67.6\%) share the view promoted by $\mathrm{Ames}^{8}$ that fruits and vegetables contain natural substances that are carcinogenic (Statement 5a). Nearly three-quarters (73.7\%) of the respondents also agreed that "people worry more than necessary about getting cancer from 
exposure to chemicals.' Only one-third (32.4\%) agreed with Statement 5c: 'Even excluding lung cancer and taking age into account, there has been a trend toward more risk from cancer over the past several decades'; $45.8 \%$ disagreed, and $21.8 \%$ were undecided. About half of the toxicologists agreed that "children of fathers exposed to high doses of radiation are more likely to develop leukaemia' (Statement 5d); however, a high number (34.6\%) marked 'don't know/no opinion' on this issue.

Insert Table 6 about here

The eight statements in Category 6 (Table 7) explored attitudes and opinions about local and national environmental health risks. A strong majority (87.5\%) disagreed that there were serious environmental health problems where they lived (Statement 6a). There was also substantial disagreement that the air and water in Britain are more contaminated now then ever before (Statements $6 \mathrm{~b}$ and $6 \mathrm{c} ; 65.4 \%$ and $62.8 \%$ disagreement, respectively). A strong majority $(86.6 \%)$ also disagreed that the quality of drinking water in the UK is unsatisfactory and poses a risk to health (Statement $6 \mathrm{~h}$ ). A moderate level of disagreement (54.8\%) was indicated to Statement 6g, 'Bathing beaches in the UK are so polluted that it is unsafe to swim in the sea.'

Insert Table 7 about here

Responses were more divided on the remaining three statements in Category 6 (Statements $6 \mathrm{~d}, 6 \mathrm{e}$, and $6 \mathrm{f}$ ). In response to an assertion that the 'fallout from the Chernobyl accident will increase the incidence of cancer among UK residents,' $42.6 \%$ agreed, but $30.4 \%$ were undecided. Similarly, $41.3 \%$ agreed that 'living near the nuclear reprocessing facility in Sellafield, Cumbria is likely to affect health adversely'; $38.1 \%$ disagreed and $20.5 \%$ were 
undecided. In response to the statement 'municipal incinerators pollute the environment and cause adverse effects on the health of the local population,' $37.8 \%$ agreed, $35.0 \%$ disagreed, and $27.2 \%$ were undecided.

Category 7 (Table 8) includes five statements designed to assess the respondents' general attitudes about the objectivity of scientific inquiry and risk assessment. An overwhelming majority (91.0\%) agreed with the view that 'when emotions influence scientific judgments, rationality suffers.' The strength of this opinion is demonstrated by the high number of strongly agree responses (42.9\%). A strong majority (71.1\%) also thought that when scientists deal with issues of high uncertainty, facts and values frequently merge (Statement 7c). However, 19.2\% were undecided on this question. Nearly two-thirds (63.5\%) agreed that 'risk is a subjective construct created through a mix of technical assumptions and personal and social values' (Statement 7e). When it came to risk assessment, the responses to Statement $7 \mathrm{~b}$ indicated that most toxicologists $(60.9 \%)$ thought it was an objective scientific process. However, $61.6 \%$ of the respondents agreed that risk assessment should be kept separate from risk management (Statement 7d).

Insert Table 8 about here

Three miscellaneous questions are contained in Category 8 (Table 9). A large majority (83.7\%) disagreed with the assertion in Statement 8a that natural chemicals are less harmful than man-made chemicals, in contrast to the view forcefully proposed by Rachel Carson in $\underline{\text { Silent }}$ Spring. Three-quarters disagreed that people should be accept some risks to their health in order to strengthen the economy (Statement $8 \mathrm{~b}$ ). Most toxicologists (67.0\%) agreed that 'experts are able to make reasonably accurate quantitative estimates of the health risks from chemicals in the 
environment' (Statement 8c). The confidence expressed by responses to this statement stands in contrast to the equivocal response to inferences from animal studies, as expressed in responses to $2 a, 2 b$, and $2 c$ (see Table 3). The reason for this inconsistency is not understood.

Insert Table 9 about here

\section{Worldviews}

Response distributions for questions pertaining to worldviews (also known as cultural biases or orienting positions) are shown as Category 9 in Table 10. A vast majority of respondents (82.1\%) disagreed with the fatalistic view in Statement 9a to the effect that they had little control over risks to their health. Responses were mixed to the two statements reflecting adherence to hierarchical forms of social organization. In $9 \mathrm{~b}, 57.1 \%$ agreed that decisions about health risks should be left to the experts. In $9 c, 60.3 \%$ agreed that people in positions of authority tend to abuse their power. The individualistic statement that people with more ability should earn more (Statement $9 \mathrm{~d}$ ) was supported by $79.4 \%$ of the respondents. Egalitarianism, as expressed in Statement $9 \mathrm{e}$, received mixed responses with $46.8 \%$ agreement and $39.4 \%$ disagreement that 'if people in this country were treated more equally, we would have fewer problems.' There was substantial agreement $(73.1 \%)$ with the view that a high technological society is important for improving our health and social well being (Statement 9f). Thirty-nine percent agreed that when a risk is very small, it is okay for society to impose that risk on individuals without their consent (Statement $9 \mathrm{~g}$ ), and more than half (54.2\%) agreed that continued economic growth is necessary to improve our quality of life (Statement 9h).

Insert Table 10 about here 


\section{Attitudes and opinions: Differences between men and women toxicologists}

Large gender differences were observed on several attitude and opinion items. Men were much more likely to agree that people worry more than necessary about getting cancer from exposure to chemicals and that when the risk is very small, it is OK for society to impose that risk on individuals without their consent (all differences in response frequency cited in this section were $10 \%$ or greater and were significant at $\mathrm{p}<.05$ or better). Women were more likely to agree that it can never be too expensive to reduce the risks associated with chemicals and that:

- Bathing beaches in the UK are so polluted that it is unsafe to swim in the sea

- Living near the nuclear reprocessing facility in Sellafield, Cumbria, is likely to affect health adversely

- There has been a trend toward more risk from cancer over the past several decades

- Municipal incinerators cause pollution and adverse effects on the health of local the population

- The children of fathers exposed to high doses of radiation are more likely to develop leukaemia

Women also tended to exhibit less sensitivity to dose and its relation to health risk, with more agreement that 'if a carcinogen were found in my tap water at levels below regulatory concern, I would not drink the water.' Men were more likely to agree that a threshold dose for both genotoxic and nongenotoxic carcinogens exists, below which they do not include neoplasms. Men also exhibited more agreement that a high technology society is important for improving our health and social well-being. 
Men were more likely to agree that risk assessment should be kept separate from risk management. Men were also more likely to agree that how an animal reacts to a chemical is a reliable predictor of how a human would react to it; women, however, were more likely to agree that if a study produces evidence that a chemical causes cancer in animals, then it will cause cancer in humans. Men exhibited more trust that experts can make accurate estimates of the health risks form chemicals in the environment.

\section{The risk-perception index}

A risk-perception index was created for each respondent by averaging his or her ratings across all 29 hazard items. For the purposes of averaging responses, "almost no risk" was coded as 1, "slight risk" as 2, "moderate risk" as 3, and "high risk" as 4 . About $80 \%$ of these mean responses fell between 1.5 and 2.5 . Only $2.9 \%$ of the respondents had a mean value greater than 3.0 (the 'moderate-risk' response). The median value was in the vicinity of the 'slight risk' category.

The risk-perception index was correlated with responses to the attitude, opinion, and worldview statements presented in tables 2 through 11 . The correlation between the index and each statement is presented in parentheses after the statement in tables 2 through 11 . The riskperception index was significantly correlated with at least one statement from every category. In general, high correlations were found for items in Category 1 (Table 2; general opinions about health risks from chemicals), Category 5 (Table 6; other questions pertaining to cancer), and Category 6 (Table 7; local and national environmental health risks). Persons who had higher average ratings of risk across the 29 items tended to have generally negative attitudes toward chemicals, with less sensitivity to dose-response relationships, and with greater concern about the 
environment. In Table 2, for example, the index correlated .42 with the view that 'our society has perceived only the tip of the iceberg with regard to the risks associated with chemicals'

(Statement 1c). Toxicologists with higher average risk ratings tended to support the view that carcinogenicity studies in animals (Statements $2 \mathrm{~d}$ through $2 \mathrm{~h}$ ) and cancer risk-assessment models (Statements $2 \mathrm{i}$ through $2 \mathrm{k}$ ) tended to underestimate the risks to humans. They tended to disagree that chemical risks are sufficiently regulated (Statement 3a) and disagree that people worry more than necessary about getting cancer from exposure to chemicals (Statement $5 b$ ). They were also more likely to agree that natural chemicals are less harmful than man-made chemicals (Statement 8a) and to disagree that small risks should be imposed on people without their consent (Statement 9g).

\section{Technical evaluations}

Another feature of this survey was the inclusion of two sets of technical evaluations for Chemical B and Compound E. The response distributions for questions about Chemical B are shown in Table 11. The percentage of respondents whose responses agreed with that of the majority of the National Toxicology Program panel ranged from $70.5 \%$ for female mice to $27.9 \%$ for male mice. Only eight persons (2.6\%) matched the judgment of the NTP panel on all four studies. Except for female mice, there was considerable spread in the response distributions, reflecting differences of opinion among the respondents.

Insert Table 11 about here

There was considerable disagreement about whether animal studies of the type performed by the NTP will permit reliable judgments of the likelihood that the chemical is carcinogenic in humans; only $53.2 \%$ agreed and $40.7 \%$ disagreed. Despite these concerns, $64.7 \%$ rated Chemical 
$\mathrm{B}$ as a probable or possible carcinogen in humans (Statement B7) and $46.8 \%$ agreed that $1 \mathrm{ppb}$ of the chemical in indoor air would be acceptable (Statement B6).

Evaluations of Compound E are shown in Table 12. Most respondents (78.5\%) judged its toxicity to be in the low to moderate range. Most respondents (67.3\%) also disagreed that the presence of Compound $\mathrm{E}$ in rubber baby bottle nipples is acceptable.

Insert Table 12 about here

The risk-perception index described earlier was found to correlate significantly $(\underline{r}=-.13$, item B6) with the acceptability of Chemical B in indoor air (those with higher risk ratings were less likely to judge Chemical B as acceptable); with the evaluation of Chemical B as a probable human carcinogen $(\underline{r}=-.14$, item B7), and with the judgments of toxicity of Compound E $(\underline{r}=.14$, item $\mathrm{E} 1)$.

Each respondent was given a score (called the pattern index) based on his or her evaluations of the four studies with Chemical B (items B1 to B4). A response of clear evidence or some evidence was coded as 1; equivocal evidence as 2 ; and no or inadequate evidence as 3 . These values were summed over the four responses. A low score on the index indicated a tendency to see strong evidence for carcinogenicity in each of the four studies. This index was correlated with the individual item ratings of risk for the 29 hazards and with the attitudes and opinions expressed in the rest of the survey. Respondents with a tendency to see strong evidence of carcinogenicity in the four studies were more likely to:

- see high risk to society from depletion of the ozone $(\underline{r}=-.13)$

- agree that the way an animal reacts to a chemical is a reliable predictor of how a human would react to it $(\underline{r}=-.14)$ 
- agree that a scientific study producing evidence that a chemical causes cancer in animals it would probably cause cancer in humans $(\underline{r}=-.12)$

- disagree that risk is a subjective construct created through a mix of technical assumptions and personal and social values $(\underline{r}=.15)$

- agree that animal studies of the type done with Chemical B will permit one to make reliable judgments of the likelihood that the chemical is carcinogenic in humans $(\underline{r}=-$ $.28)$

- $\underline{\text { disagree that }}$ Compound $\mathrm{E}$ is acceptable in rubber baby bottle nipples $(\underline{\underline{r}}=-.13)$

- have spent more years conducting experimental work $(\underline{r}=-.19)$

- have worked frequently with animal test systems $(\underline{r}=-.16)$

\section{Affiliation effects}

Previous research ${ }^{1,5}$ found that toxicologists in industry were somewhat less inclined than other toxicologists to agree that a study producing evidence that a chemical causes cancer in animals indicates that we can be reasonably sure that the chemical will cause cancer in humans. Kraus et al. found that only $22 \%$ of toxicologists working in industry endorsed this view, compared to $48.9 \%$ and $52.7 \%$ endorsement among academics and government employees. This tendency was replicated with item $2 b$ in the present study, though the discrepancy was much smaller. Whereas $29.7 \%$ of those in industry endorsed this statement, $39.3 \%$ and $35.2 \%$ of the academics and government employees endorsed it. Unlike the study by Kraus et al., differences were also found in response to the general statement (2a) about animal testing ('The way that an animal reacts to a chemical is a reliable predictor of how a human would react to it'), with $51.7 \%$ of industry employees, $50.0 \%$ of government employees, and $36.9 \%$ of academics agreeing. 
Thus there was not much difference in the responses of the academics to these two statements (2a and $2 b$ ), whereas government and industry employees indicated much greater agreement with the general statement about animal testing (2a) than where the study was said to have found evidence for cancer $(2 b)$.

Examination of the responses to the 29 hazards showed that academics tended to have the highest perceptions of risk for most of the items. In particular, academics gave more than $15 \%$ more responses in the moderate and high-risk categories than government employees for nuclear power reactors, nuclear waste, outdoor air pollution, and pesticides in food. In comparison to industry employees, academics gave more than $15 \%$ more moderate and high-risk responses for alcoholic beverages, prescription drugs, chemical pollution in the workplace, suntanning, nuclear power reactors, and nonprescription drugs. There were three items (prescription drugs, chemical pollution in the workplace, and suntanning) for which government employees gave more than $15 \%$ more moderate and high-risk responses than did private industry employees. There were no items for which the private industry respondents had $15 \%$ or more moderate and high-risk responses in comparison with other groups.

Although there were other attitude and opinion statements that were correlated with affiliation, these differences will not be addressed in detail in this report. For example, academics spent more time doing research than did toxicologists in government and industry. Academics also worked more with in vitro systems, and were less experienced in doing risk assessment and toxicological work. Those in industry had more experience in toxicological and testing types of work whereas those in government were more experienced in risk assessment and risk characterization. Women were more likely to work in academia, with females representing 
$38.1 \%$ of the academic respondents, $33.3 \%$ of the government employees, and $22.9 \%$ of the industry employees. In summary, affiliation effects exist, but sorting out the underlying causes from the wealth of confounding factors will take further research focused specifically on this topic.

\section{Risk perceptions, attitudes, opinions, and worldviews: Comparisons with Canadian and European toxicologists}

Two similar surveys of toxicologists were conducted in 1993 using samples from the European Society of Toxicologists $(\underline{N}=125)$ and the Canadian Society of Toxicologists $(\underline{N}=$ 150). Figures 3 and 4 compare the moderate and high-risk responses for the British toxicologists with the European and Canadian toxicologists across the risk items given in each survey.

Insert Figures 3 and 4 about here

In general, British toxicologists tended to have lower risk perceptions for most items. The major exception was asbestos; British toxicologists had $25 \%$ or more moderate or high-risk responses to this hazard than either the European or Canadian toxicologists. They also tended to have higher risk perceptions for cigarette smoking than the other two groups. In addition, the British exhibited higher risk perceptions for dioxins compared to the European toxicologists. (Dioxins was not included as a hazard on the Canadian survey.) Items for which the British toxicologists had over $15 \%$ fewer moderate or high-risk responses than the European respondents were ozone depletion, motor vehicle accidents, alcoholic beverages, chemical pollution in the environment, and outdoor air pollution. Items for which the British respondents gave fewer moderate and high-risk responses than the Canadians were ozone depletion, motor vehicle 
accidents, suntanning, chemical pollution in the environment, alcoholic beverages, medical Xrays, and food additives.

There were 18 attitudinal questions on the 1993 Canadian study that were included in the present survey. The differences in percent agreement between the British and Canadian responses on these items are displayed in Figure 5. There were several large differences. The British toxicologists were much more likely to feel that the government had no right to regulate personal risk-taking activities with $32.0 \%$ more agree responses than the Canadian toxicologists.

However, the British were more likely to be willing to leave decisions about health risks to the experts with $57.1 \%$ agreement compared to only $31.3 \%$ of the Canadian toxicologists; a $25.7 \%$ difference. The British were also more likely to believe that the experts are able to make reasonably accurate quantitative estimates of the health risks from chemicals in the environment (with $23.7 \%$ more agree responses than the Canadian respondents). In addition, other items for which the British toxicologists recorded over $10 \%$ more agreement were:

- People in positions of authority tend to abuse their power.

- Chemical risks are sufficiently regulated in this country.

- If people in this country were treated more equally, we would have fewer problems. Items for which the Canadian toxicologists recorded over $10 \%$ more agree responses than the British were:

- The way that an animal reacts to a chemical is a reliable predictor of how a human would react to it.

- If a scientific study produces evidence that a chemical causes cancer in animals, then we can be reasonably sure that the chemical will cause cancer in humans. 
ᄃ

- I try hard to avoid contact with chemicals and chemical products in my daily life.

There are serious environmental health problems were I live.

Insert Figure 5 about here 


\section{Discussion}

In general, the British toxicologists judged risks to be quite low for most chemical hazards-their perceived risk responses were, in general, even lower than those of Canadian and European toxicologists. Exceptions to this were cigarette smoking and asbestos, hazards that the British toxicologists rated extremely high on risk. In keeping with their ratings of chemical risks as small, British toxicologists had quite favorable attitudes toward the use of chemicals, had confidence in the regulation of chemicals, and did not feel concerned about air and water contamination in the nation or in their local environment.

As with previous studies of toxicologists in the U.S., Canada, and Europe, British toxicologists showed strong effects of gender in their evaluations. For almost every hazard studied, women's risk ratings were considerably higher than men's ratings. Moreover, women had consistently stronger anti-chemical attitudes.

Affiliation effects found in British toxicologists were also similar to the results of previous studies. Toxicologists working for industry were much more likely than others to disagree that a chemical inducing cancer in animals was likely to induce cancer in humans. Academic toxicologists were more likely than others to perceive chemical risks as high and to have unfavorable attitudes toward chemicals and their use.

Confidence in the ability to extrapolate from animal studies to human health effects was rather low. Toxicologists disagreed about the reliability of animal tests and tended to discount the importance of studies that found a chemical to induce cancer in animals. This discounting appears related to the belief that animal studies overestimate risks to humans because of cytotoxic effects associated with high doses given to animals. Despite these problems, however, 
about two-thirds of the respondents believed that experts could make reasonably accurate quantitative estimates of health risks from chemicals in the environment.

When asked to evaluate technical summaries of various animal studies, there was considerable disagreement among the toxicologists and disagreement with the judgments of NTP panels. About $40 \%$ of the respondents disagreed that animal studies of this type permit reliable extrapolation to humans.

The present survey shows considerable similarity between British toxicologists and their colleagues in other countries. However, the large sample size in this survey permits more reliable analysis of factors such as gender and affiliation and such effects were found to be large and statistically significant. Further research will be necessary to determine their scientific and political importance.

Perhaps the most intriguing finding in this and previous surveys is the disagreement about the value of animal studies and the skepticism about the ability to extrapolate from a positive finding of carcinogenicity in animals to human health effects. The skepticism shown in these surveys is consistent with numerous articles in the recent literature discussing scientists' concerns about the validity of animal tests (see, for example, ref. 9). Previous studies have shown that the public interprets positive findings in animal studies as strong evidence that a chemical will be carcinogenic in humans. These survey results suggest that animal studies do a good job of frightening the public without providing evidence that scientists see as convincing. Animal studies may thus be a contributing factor to the public's high perceived risk for chemicals and general anti-chemical attitudes. 


\section{Acknowledgments}

This paper was supported by the U.S. National Science Foundation under grants SES9122178 and SBR-9422794 to Decision Research. We thank the members of the British Toxicology Society for their participation in the study. We also thank Leisha Mullican and Kari Nelson for their assistance in the preparation of the manuscript and Molly Dack for distributing and collecting the questionnaires. 


\section{References}

1 Kraus, N, Malmfors T \& Slovic P. Intuitive toxicology: Expert and lay judgments of chemical risks. Risk Analysis 1992; 12: 215-232.

2 Rozin P, Millman L \& Nemeroff C. Operation of the laws of sympathetic magic in disgust and other domains. Journal of Personality and Social Psychology 1986; 50: 703712.

3 Krewski D, Slovic P, Bartlett S, Flynn J \& Mertz CK. Health risk perception in Canada I: Rating hazards, sources of information and responsibility for health protection. $\underline{\text { Human }}$ and Ecological Risk Assessment 1995; 1(2): 117-132.

4 Slovic P, Flynn J, Mertz CK \& Mullican L. Health-Risk Perception in Canada (Report No. 93-EHD-170). Department of National Health and Welfare, Ottawa, 1993.

5 Slovic P, Malmfors T, Krewski D, Mertz CK, Neil N \& Bartlett S. Intuitive toxicology II: Expert and lay judgments of chemical risks in Canada. Risk Analysis 1995; 15(6): 661675.

6 Dake K. Orienting dispositions in the perception of risk: An analysis of contemporary worldviews and cultural biases. Journal of Cross-Cultural Psychology 1991; 22(1): 61 82.

7 Peters E \& Slovic P. The role of affect and worldviews as orienting dispositions in the

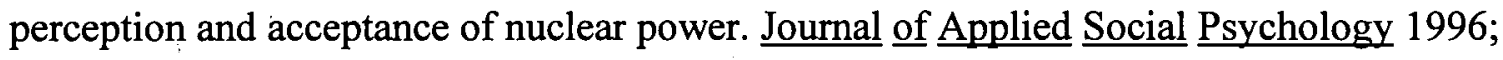
26(16): 1427-1453.

8 Ames BN: Dietary carcinogens and anticarcinogens. Science 1983; 221: 1256-1263.

9 Griffiths S. Design and evaluation of carcinogenicity studies: Is the existing rodent bioassay meaningful? [Summary of the Second International Conference of the 
International Federation of Societies of Toxicologic Pathology entitled 'Carcinogens:

New methods-interpretation-risk assessment,' Tours, France, April 1995]. $\underline{\text { CMR }} \underline{\text { News }}$ 1995; 13(2): 6-7. 


\section{Table 1. Information Presented for the Evaluation of} Chemical B

\section{Summary of the Two-Year Inhalation and Genetic Toxicology Studies of Chemical B}

\begin{tabular}{|c|c|c|c|}
\hline Male F344/N Rats & Female F344/N Rats & Male B6C3F 1 Mice & Female $\mathrm{B}_{6} \mathrm{C}_{3} \mathrm{~F}_{1}$ Mice \\
\hline $\begin{array}{l}0,100,200, \text { or } 400 \mathrm{ppm} \\
\text { Chemical } \mathrm{B}, 6 \mathrm{~h} / \mathrm{d}, 5 \mathrm{~d} / \mathrm{wk}\end{array}$ & $\begin{array}{l}0,100,200, \text { or } 400 \mathrm{ppm} \\
\text { Chemical } \mathrm{B}, 6 \mathrm{~h} / \mathrm{d}, 5 \mathrm{~d} / \mathrm{wk}\end{array}$ & $\begin{array}{l}0,100,200, \text { or } 400 \mathrm{ppm} \\
\text { Chemical } \mathrm{B}, 6 \mathrm{~h} / \mathrm{d}, 5 \mathrm{~d} / \mathrm{wk}\end{array}$ & $\begin{array}{l}0,100,200, \text { or } 400 \mathrm{ppm} \\
\text { Chemical B, } 6 \mathrm{~h} / \mathrm{d}, 5 \mathrm{~d} / \mathrm{wk}\end{array}$ \\
\hline Exposed and control similar & $\begin{array}{l}\text { Exposed and control generally } \\
\text { similar }\end{array}$ & $\begin{array}{l}\text { Exposed and control generally } \\
\text { similar }\end{array}$ & $\begin{array}{l}\text { 400-ppm group lower than } \\
\text { controls }(6-16 \%)\end{array}$ \\
\hline Survival rates & $19 / 50 ; 29 / 50 ; 24 / 49 ; 23 / 50$ & $35 / 50 ; 37 / 50 ; 30 / 50 ; 34 / 50$ & $36 / 50 ; 37 / 50 ; 37 / 49 ; 23 / 49$ \\
\hline $\begin{array}{l}\text { Alveolar and nasal epithelial } \\
\text { hyperplasia, suppurative } \\
\text { inflammation of nasal cavity }\end{array}$ & $\begin{array}{l}\text { Alveolar and nasal epithelial } \\
\text { hyperplasia }\end{array}$ & None & Inflammation of the lung \\
\hline $\begin{array}{l}\text { Neoplastic effects } \\
\text { Adrenal gland: } \\
\text { pheochromocytomas }(8 / 40 ; \\
23 / 45 ; 18 / 46 ; 21 / 46) ; \text { brain: } \\
\text { granular cell tumors } \mathrm{a}(0 / 49 ; \\
3 / 50 ; 1 / 50 ; 1 / 50) ; \text { glial cell } \\
\text { tumors }(0 / 49,3 / 50,0 / 50,0 / 50) \text {; } \\
\text { lung: alveolar/bronchiolar } \\
\text { adenomas or carcinomas } \\
\left(\text { combined) }{ }^{b}(0 / 48 ; 0 / 49 ; 4 / 48 ;\right. \\
1 / 48)\end{array}$ & $\begin{array}{l}\text { Brain: gliomas }{ }^{\mathrm{C}}(0 / 50 ; 1 / 50 ; \\
\text { 1/48; } 3 / 50) ; \text { lung: } \\
\text { alveolar/bronchiolar adenomas }{ }^{\mathrm{d}} \\
(0 / 50 ; 0 / 48 ; 0 / 47 ; 3 / 49) ; \\
\text { mammary gland: neoplasms } \\
(18 / 50 ; 15 / 50 ; 10 / 48 ; 7 / 50)\end{array}$ & $\begin{array}{l}\text { Lung: alveolar/bronchiolar } \\
\text { adenomas or carcinomas } \\
\text { (combined) }(7 / 50 ; 6 / 50 ; 12 / 50 \text {; } \\
15 / 50)\end{array}$ & $\begin{array}{l}\text { Uterus: adenomas, } \\
\text { adenocarcinomas, or squamous } \\
\text { cell carcinomas (combined) } \\
(0 / 50 ; 4 / 50 ; 5 / 47 ; 27 / 48)\end{array}$ \\
\hline \multicolumn{4}{|l|}{ Genetic toxicology } \\
\hline \multicolumn{2}{|c|}{ Salmonella (gene mutation) } & SCE & Aberration \\
\hline \multicolumn{2}{|c|}{$\begin{array}{l}\text { Positive with and without } \mathbf{S} 9 \\
\text { in vapor assay }\end{array}$} & $\begin{array}{l}\text { Positive with and } \\
\text { without S9 }\end{array}$ & $\begin{array}{l}\text { Negative with } \\
\text { and without S9 }\end{array}$ \\
\hline
\end{tabular}

a historical control 0/297

b historical control 6/299

${ }^{c}$ historical control: untreated 23/1,969; chamber 1/297

d historical control 4/297 
Table 2. Responses to Attitude and Opinion Statements: Category 1

General Opinions About Health Risks From Chemicals

\begin{tabular}{|c|c|c|c|c|c|c|c|}
\hline & & & $\begin{array}{l}\text { Strongly } \\
\text { disagree }\end{array}$ & Disagree & Agree & $\begin{array}{c}\text { Strongly } \\
\text { agree }\end{array}$ & $\begin{array}{c}\text { Don't know/ } \\
\text { no opinion }\end{array}$ \\
\hline Q61 & $1 \mathrm{a}$. & $\begin{array}{l}\text { In general, use of chemicals has } \\
\text { improved our health more than it has } \\
\text { harmed it }(-.22)\end{array}$ & 0.3 & 2.6 & 55.1 & 38.1 & 3.8 \\
\hline Q48 & 1b. & $\begin{array}{l}\text { I try hard to avoid contact with } \\
\text { chemicals and chemical products in my } \\
\text { daily life }(.28)\end{array}$ & 26.6 & 52.2 & 15.1 & 3.5 & 2.6 \\
\hline Q45 & 1c. & $\begin{array}{l}\text { Our society has perceived only the tip } \\
\text { of the iceberg with regard to the risks } \\
\text { associated with chemicals }(.42)\end{array}$ & 4.5 & 55.1 & 26.6 & 6.7 & 7.1 \\
\hline Q47 & $1 \mathrm{~d}$. & $\begin{array}{l}\text { It can never be too expensive to reduce } \\
\text { the risks associated with chemicals } \\
(.30)\end{array}$ & 16.3 & 59.3 & 14.1 & 8.3 & 1.9 \\
\hline
\end{tabular}

Note. Cell entries are percentages. Values in parentheses are correlations between responses to the statement and the risk-perception index. Correlations greater than .11 are significant at $\mathrm{p}<.05$. Correlations greater than .16 are significant at $\mathrm{p}<.01$. 
Table 3. Responses to Attitude and Opinion Statements: Category 2

Trust in the Use of Animal and Epidemiological Studies to Determine Human Health Risk

\begin{tabular}{|c|c|c|c|c|c|c|c|}
\hline & & & $\begin{array}{l}\text { Strongly } \\
\text { disagree }\end{array}$ & Disagree & Agree & $\begin{array}{l}\text { Strongly } \\
\text { agree }\end{array}$ & $\begin{array}{c}\text { Don't know/ } \\
\text { no opinion }\end{array}$ \\
\hline Q32 & 2a. & $\begin{array}{l}\text { The way that an animal reacts to a } \\
\text { chemical is a reliable predictor of how } \\
\text { a human would react to it }(-.12)\end{array}$ & 5.4 & 43.3 & 44.6 & 3.5 & 3.2 \\
\hline Q34 & $2 b$. & $\begin{array}{l}\text { If a scientific study produces evidence } \\
\text { that a chemical causes cancer in } \\
\text { animals, then we can be reasonably } \\
\text { sure the chemical will cause cancer in } \\
\text { humans }(.20)\end{array}$ & 12.5 & 50.6 & 32.7 & 2.2 & 1.9 \\
\hline \multirow[t]{2}{*}{ Q35 } & $2 c$. & $\begin{array}{l}\text { Laboratory studies of a chemical's } \\
\text { harmful effects on animals allow } \\
\text { scientists to accurately determine how } \\
\text { much of the chemical it takes to cause } \\
\text { similar harm in humans }(-.01)\end{array}$ & 10.9 & 58.0 & 26.0 & 3.8 & 1.3 \\
\hline & & \multicolumn{6}{|c|}{ In general, carcinogenicity studies in animals ... } \\
\hline Q56 & $2 \mathrm{~d}$. & $\begin{array}{l}\text {.. overestimate risks to humans } \\
\text { because some animal studies produce } \\
\text { carcinogenic effects due to cytotoxic or } \\
\text { other effects that occur only at high } \\
\text { doses }(-.16)\end{array}$ & 1.0 & 9.6 & $\begin{array}{c}61.5 \\
. .\end{array}$ & 24.0 & 3.8 \\
\hline Q57 & $2 \mathrm{e}$. & $\begin{array}{l}\ldots \text { overestimate risks to humans due to } \\
\text { use of animals that are extremely } \\
\text { sensitive (cancer prone) }(-.07)\end{array}$ & 1.0 & 41.3 & 42.3 & 7.4 & 8.0 \\
\hline Q58 & $2 f$. & $\begin{array}{l}\text {.. overestimate risks to humans } \\
\text { because human exposures are quite } \\
\text { small compared to the levels of } \\
\text { exposures to animals in these studies (- } \\
\text {.10) }\end{array}$ & 1.0 & 17.0 & 66.0 & 11.9 & 4.2 \\
\hline Q59 & $2 \mathrm{~g}$. & $\begin{array}{l}\ldots \text { underestimate risks to humans } \\
\text { because there is greater genetic } \\
\text { diversity in the human population than } \\
\text { there is in laboratory animals }(.23)\end{array}$ & 2.6 & 49.0 & 30.8 & 2.6 & 15.1 \\
\hline Q60 & $2 \mathrm{~h}$. & $\begin{array}{l}\text {. . underestimate risks to humans due } \\
\text { to synergistic effects among the many } \\
\text { substances that humans are exposed to } \\
\text { (.37) }\end{array}$ & 2.6 & 35.9 & 36.9 & 3.8 & 20.8 \\
\hline
\end{tabular}

(Table 3 continues) 
(Table 3, continued)

\begin{tabular}{|c|c|c|c|c|c|c|c|c|}
\hline & & ( & $\begin{array}{c}\text { Much } \\
\text { overest }\end{array}$ & Overest & $\begin{array}{c}\text { Neither } \\
\text { overest } \\
\text { nor } \\
\text { underest }\end{array}$ & Underest & $\begin{array}{c}\text { Much } \\
\text { underest }\end{array}$ & $\begin{array}{c}\text { Don't } \\
\text { know/no } \\
\text { opinion }\end{array}$ \\
\hline Q67 & $2 \mathrm{i}$. & $\begin{array}{l}\text { Do cancer risk-assessment models tend to } \\
\text { overestimate or underestimate risk when } \\
\text { extrapolating laboratory data from high to } \\
\text { low doses? }(.27)\end{array}$ & 7.7 & 63.5 & 6.7 & 3.8 & - & 18.3 \\
\hline Q68 & $2 \mathrm{j}$. & $\begin{array}{l}\text { Do cancer risk-assessment models tend to } \\
\text { overestimate or underestimate risk when } \\
\text { extrapolating data from animals to humans? } \\
(.28)\end{array}$ & 6.7 & 63.5 & 9.9 & 2.6 & - & 17.3 \\
\hline Q69 & $2 \mathrm{k}$ & $\begin{array}{l}\text { Do epidemiological studies tend to } \\
\text { overestimate or underestimate cancer risks } \\
\text { from chemicals? }(.15)\end{array}$ & 11.9 & 48.1 & 20.5 & 0.3 & - & 19.2 \\
\hline
\end{tabular}

Note. Cell entries are percentages. Values in parentheses are correlations between responses to the statement and the risk-perception index. Correlations greater than .11 are significant at $\mathrm{p}<.05$. Correlations greater than .16 are significant at $\mathrm{p}<.01$. 
Table 4. Responses to Attitude and Opinion Statements: Category 3

Attitudes Toward Regulation

\begin{tabular}{|c|c|c|c|c|c|c|c|}
\hline & & . & $\begin{array}{l}\text { Strongly } \\
\text { disagree }\end{array}$ & Disagree & Agree & $\begin{array}{l}\text { Strongly } \\
\text { agree }\end{array}$ & $\begin{array}{c}\text { Don't know/ } \\
\text { no opinion }\end{array}$ \\
\hline$\overline{\mathrm{Q} 43}$ & 3a. & $\begin{array}{l}\text { Chemical risks are sufficiently regulated } \\
\text { in this country }(-.29)\end{array}$ & 3.5 & 27.6 & 55.8 & 7.7 & 5.4 \\
\hline Q98 & $3 b$. & $\begin{array}{l}\text { Government has no right to regulate } \\
\text { people's personal risk-taking activities } \\
\text { such as drinking alcohol, mountain } \\
\text { climbing, etc. }(.00)\end{array}$ & 3.2 & 37.2 & 44.9 & 12.5 & 2.2 \\
\hline
\end{tabular}

Note. Cell entries are percentages. Values in parentheses are correlations between responses to the statement and the risk-perception index. Correlations greater than .11 are significant at $\mathbf{p}<.05$. Correlations greater than .16 are significant at $\mathrm{p}<.01$. 
Table 5. Responses to Attitude and Opinion Statements: Category 4

Relationship Between Level of Exposure and Health Risk

\begin{tabular}{|c|c|c|c|c|c|c|c|}
\hline & & & $\begin{array}{l}\text { Strongly } \\
\text { disagree }\end{array}$ & Disagree & Agree & $\begin{array}{c}\text { Strongly } \\
\text { agree }\end{array}$ & $\begin{array}{c}\text { Don't know/ } \\
\text { no opinion }\end{array}$ \\
\hline$\overline{\mathrm{Q} 38}$ & $4 a$. & $\begin{array}{l}\text { If a person is exposed to a chemical that } \\
\text { can cause cancer then that person will } \\
\text { probably get cancer some day (.19) }\end{array}$ & 26.3 & 64.4 & 6.7 & 1.0 & 1.6 \\
\hline Q49 & $4 b$. & $\begin{array}{l}\text { If a carcinogen were found in my tap } \\
\text { water at levels below regulatory } \\
\text { concern, I wouldn't drink the water } \\
(.27)\end{array}$ & 16.0 & 47.4 & 22.4 & 5.1 & 9.0 \\
\hline Q36 & $4 c$. & $\begin{array}{l}\text { There is a threshold dose for genotoxic } \\
\text { carcinogens, below which they do not } \\
\text { induce neoplasms }(-.09)\end{array}$ & 14.4 & 44.6 & 30.4 & 1.9 & 8.7 \\
\hline Q37 & $4 \mathrm{~d}$. & $\begin{array}{l}\text { There is a threshold dose for } \\
\text { nongenotoxic carcinogens, below } \\
\text { which they do not induce neoplasms } \\
(-.20)\end{array}$ & 3.5 & 12.5 & 51.0 & 25.0 & 8.0 \\
\hline
\end{tabular}

Note. Cell entries are percentages. Values in parentheses are correlations between responses to the statement and the risk-perception index. Correlations greater than .11 are significant at $\underline{p}<.05$. Correlations greater than .16 are significant at $\mathrm{p}<.01$. 
Table 6. Responses to Attitude and Opinion Statements: Category 5

Other Questions Pertaining to Cancer

\begin{tabular}{|c|c|c|c|c|c|c|c|}
\hline & & ; & $\begin{array}{l}\text { Strongly } \\
\text { disagree }\end{array}$ & Disagree & Agree & $\begin{array}{l}\text { Strongly } \\
\text { agree }\end{array}$ & $\begin{array}{l}\text { Don't know/ } \\
\text { no opinion }\end{array}$ \\
\hline$\overline{\mathrm{Q} 31}$ & $5 a$. & $\begin{array}{l}\text { Fruits and vegetables contain natural } \\
\text { substances that can cause cancer }(-.03)\end{array}$ & 5.1 & 19.9 & 58.0 & 9.6 & 7.4 \\
\hline Q65 & $5 b$. & $\begin{array}{l}\text { People worry more than necessary about } \\
\text { getting cancer from exposure to } \\
\text { chemicals }(-.37)\end{array}$ & 1.3 & 17.3 & 53.8 & 19.9 & 7.7 \\
\hline Q66 & $5 c$. & $\begin{array}{l}\text { Even excluding lung cancer and taking } \\
\text { age into account, there has been a trend } \\
\text { toward more risk from cancer over the } \\
\text { past several decades (.31) }\end{array}$ & 3.5 & 42.3 & 29.8 & 2.6 & 21.8 \\
\hline Q52 & $5 \mathrm{~d}$ & $\begin{array}{l}\text { The children of fathers exposed to high } \\
\text { doses of radiation are more likely to } \\
\text { develop leukeamia }(.27)\end{array}$ & 2.2 & 12.8 & 46.2 & 4.2 & 34.6 \\
\hline
\end{tabular}

Note. Cell entries are percentages. Values in parentheses are correlations between responses to the statement and the risk-perception index. Correlations greater than .11 are significant at $\mathrm{p}<.05$. Correlations greater than .16 are significant at $\mathrm{p}<.01$. 
Table 7. Responses to Attitude and Opinion Statements: Category 6

Local and National Environmental Health Risks

\begin{tabular}{|c|c|c|c|c|c|c|c|}
\hline & & & $\begin{array}{l}\text { Strongly } \\
\text { disagree }\end{array}$ & Disagree & Agree & $\begin{array}{l}\text { Strongly } \\
\text { agree }\end{array}$ & $\begin{array}{l}\text { Don't know/ } \\
\text { no opinion }\end{array}$ \\
\hline$\overline{\mathrm{Q} 30}$ & $6 a$. & $\begin{array}{l}\text { There are serious environmental health } \\
\text { problems where I live }(.42)\end{array}$ & 32.7 & 54.8 & 7.7 & 2.9 & 1.9 \\
\hline Q63 & $6 b$. & $\begin{array}{l}\text { In general, the air in our country is } \\
\text { more contaminated now than ever } \\
\text { before }(.29)\end{array}$ & 12.8 & 52.6 & 21.8 & 5.8 & 7.1 \\
\hline Q64 & 6c. & $\begin{array}{l}\text { In general, the water in our country is } \\
\text { more contaminated now than ever } \\
\text { before }(.30)\end{array}$ & 13.1 & 49.7 & 20.8 & 4.2 & 12.2 \\
\hline Q50 & $6 \mathrm{~d}$. & $\begin{array}{l}\text { Fallout from the Chernobyl accident } \\
\text { will increase the incidence of cancer } \\
\text { among UK residents }(.21)\end{array}$ & 2.9 & 24.0 & 40.7 & 1.9 & 30.4 \\
\hline Q51 & $6 e$. & $\begin{array}{l}\text { Living near the nuclear reprocessing } \\
\text { facility in Sellafield, Cumbria is likely } \\
\text { to affect health adversely }(.41)\end{array}$ & 3.2 & 34.9 & 35.9 & 5.4 & 20.5 \\
\hline Q53 & $6 f$. & $\begin{array}{l}\text { Municipal incinerators pollute the } \\
\text { environment and cause adverse effects } \\
\text { on the health of the local population } \\
(.51)\end{array}$ & 2.9 & 32.1 & 34.0 & 3.8 & 27.2 \\
\hline Q54 & $6 \mathrm{~g}$. & $\begin{array}{l}\text { Bathing beaches in the UK are so } \\
\text { polluted that it is unsafe to swim in the } \\
\text { sea }(.35)\end{array}$ & 6.1 & 48.7 & 33.0 & 4.5 & 7.7 \\
\hline Q55 & $6 \mathrm{~h}$. & $\begin{array}{l}\text { The quality of drinking water in the UK } \\
\text { is unsatisfactory and poses a risk to } \\
\text { health }(.30)\end{array}$ & 24.7 & 61.9 & 7.4 & 1.0 & 5.1 \\
\hline
\end{tabular}

Note. Cell entries are percentages. Values in parentheses are correlations between responses to the statement and the risk-perception index. Correlations greater than .11 are significant at $\mathrm{p}<.05$. Correlations greater than .16 are significant at $\mathrm{p}<.01$. 
Table 8. Responses to Attitude and Opinion Statements: Category 7

General Opinions About the Objectivity of Scientific Inquiry

\begin{tabular}{|c|c|c|c|c|c|c|c|}
\hline & & & $\begin{array}{l}\text { Strongly } \\
\text { disagree }\end{array}$ & Disagree & Agree & $\begin{array}{c}\text { Strongly } \\
\text { agree }\end{array}$ & $\begin{array}{l}\text { Don't know/ } \\
\text { no opinion }\end{array}$ \\
\hline$\overline{\mathrm{Q} 33}$ & $7 a$. & $\begin{array}{l}\text { When emotions influence scientific } \\
\text { judgments, rationality suffers }(-.10)\end{array}$ & 0.6 & 7.4 & 48.1 & 42.9 & 1.0 \\
\hline Q40 & $7 b$. & $\begin{array}{l}\text { Risk assessment for chemicals is not an } \\
\text { objective scientific process }(.07)\end{array}$ & 9.0 & 51.9 & 30.4 & 4.8 & 3.8 \\
\hline Q42 & $7 c$. & $\begin{array}{l}\text { Facts and values frequently merge when } \\
\text { scientists deal with issues of high } \\
\text { uncertainty }(-.06)\end{array}$ & 1.0 & 8.7 & 61.5 & 9.6 & 19.2 \\
\hline Q44 & $7 \mathrm{~d}$. & $\begin{array}{l}\text { Risk assessment (e.g., the identification } \\
\text { and quantification of risk) should be } \\
\text { kept separate from risk management (- } \\
.15 \text { ) }\end{array}$ & 2.9 & 26.3 & 51.3 & 10.3 & 9.3 \\
\hline Q46 & $7 e$. & $\begin{array}{l}\text { Risk is a subjective construct created } \\
\text { through a mix of technical assumptions } \\
\text { and personal and social values }(.03)\end{array}$ & 2.2 & 28.2 & 54.2 & 9.3 & 6.1 \\
\hline
\end{tabular}

Note. Cell entries are percentages. Values in parentheses are correlations between responses to the statement and the risk-perception index. Correlations greater than .11 are significant at $\underline{p}<.05$. Correlations greater than .16 are significant at $\mathrm{p}<.01$. 


\section{Table 9. Responses to Attitude and Opinion Statements: Category 8}

\section{Miscellaneous Questions}

\begin{tabular}{|c|c|c|c|c|c|c|c|}
\hline & & & $\begin{array}{l}\text { Strongly } \\
\text { disagree }\end{array}$ & Disagree & Agree & $\begin{array}{c}\text { Strongly } \\
\text { agree }\end{array}$ & $\begin{array}{c}\text { Don't know/ } \\
\text { no opinion }\end{array}$ \\
\hline$\overline{\mathrm{Q} 62}$ & $8 a$. & $\begin{array}{l}\text { In general, natural chemicals are less } \\
\text { harmful than man-made chemicals } \\
(.17)\end{array}$ & 29.2 & 54.5 & 9.6 & 3.2 & 3.5 \\
\hline Q103 & $8 b$. & $\begin{array}{l}\text { People should be prepared to accept } \\
\text { some risks to their health in order to } \\
\text { strengthen the economy }(-.04)\end{array}$ & 11.9 & 62.8 & 19.2 & 0.3 & 5.8 \\
\hline Q41 & $8 c$. & $\begin{array}{l}\text { Experts are able to make reasonably } \\
\text { accurate quantitative estimates of the } \\
\text { health risks from chemicals in the } \\
\text { environment }(-.08)\end{array}$ & 2.9 & 25.3 & 62.5 & 4.5 & 4.8 \\
\hline
\end{tabular}

Note. Cell entries are percentages. Values in parentheses are correlations between responses to the statement and the risk-perception index. Correlations greater than .11 are significant at $\mathrm{p}<.05$. Correlations greater than .16 are significant at $\mathrm{p}<.01$. 
Table 10. Responses to Attitude and Opinion Statements: Category 9

Worldviews

\begin{tabular}{|c|c|c|c|c|c|c|c|}
\hline & & & $\begin{array}{l}\text { Strongly } \\
\text { disagree }\end{array}$ & Disagree & Agree & $\begin{array}{c}\text { Strongly } \\
\text { agree }\end{array}$ & $\begin{array}{c}\text { Don't know/ } \\
\text { no opinion }\end{array}$ \\
\hline$\overline{\mathrm{Q} 102}$ & 9 a. & $\begin{array}{l}\text { I feel that I have very little control } \\
\text { over risks to my health (Fatalism; } \\
\text {.18) }\end{array}$ & 7.7 & 74.4 & 14.4 & 1.6 & 1.9 \\
\hline Q39 & $9 b$. & $\begin{array}{l}\text { Decisions about health risks should } \\
\text { be left to the experts (Hierarchy; } \\
-.05 \text { ) }\end{array}$ & 4.2 & 35.9 & 43.3 & 13.8 & 2.9 \\
\hline Q96 & $9 c$. & $\begin{array}{l}\text { People in positions of authority tend } \\
\text { to abuse their power (Hierarchy; } \\
.27 \text { ) }\end{array}$ & 1.0 & 30.1 & 44.6 & 15.7 & 8.7 \\
\hline Q97 & $9 \mathrm{~d}$. & $\begin{array}{l}\text { In a fair system, people with more } \\
\text { ability should earn more } \\
\text { (Individualism; .14) }\end{array}$ & 0.6 & 14.7 & 66.3 & 13.1 & 5.1 \\
\hline Q99 & $9 e$. & $\begin{array}{l}\text { If people in this country were treated } \\
\text { more equally, we would have fewer } \\
\text { problems (Egalitarianism; .12) }\end{array}$ & 2.9 & 36.5 & 38.1 & 8.7 & 13.8 \\
\hline Q95 & $9 f$. & $\begin{array}{l}\text { A high technology society is } \\
\text { important for improving our health } \\
\text { and social well-being } \\
\text { (Technological Enthusiasm; - }-12 \text { ) }\end{array}$ & 1.6 & 19.6 & 56.1 & 17.0 & 5.8 \\
\hline Q100 & $9 \mathrm{~g}$. & $\begin{array}{l}\text { When a risk is very small, it is okay } \\
\text { for society to impose that risk on } \\
\text { individuals without their consent (- } \\
\text {.13) }\end{array}$ & 9.0 & 44.2 & 38.1 & 1.0 & 7.7 \\
\hline Q101 & $9 \mathrm{~h}$. & $\begin{array}{l}\text { Continued economic growth is } \\
\text { necessary to improve our quality of } \\
\text { life }(-.05)\end{array}$ & 1.6 & 34.0 & 48.1 & 6.1 & $10: 3$ \\
\hline
\end{tabular}

Note. Cell entries are percentages. Values in parentheses are correlations between responses to the statement and the risk-perception index. Correlations greater than .11 are significant at $\mathrm{p}<.05$. Correlations greater than .16 are significant at $\mathrm{p}<.01$. 


\section{Table 11. Evaluations of Chemical B}

Q: Based on the information in the abstract you have read, what would you conclude about the level of evidence of carcinogenic activity of Chemical B for:

\begin{tabular}{llllllrc}
\hline & & & $\begin{array}{c}\text { Clear } \\
\text { evidence }\end{array}$ & $\begin{array}{c}\text { Some } \\
\text { evidence }\end{array}$ & $\begin{array}{c}\text { Equivocal } \\
\text { evidence }\end{array}$ & $\begin{array}{c}\text { No } \\
\text { evidence }\end{array}$ & $\begin{array}{c}\text { Inadequate } \\
\text { evidence }\end{array}$ \\
\hline Q78 & B1: & Male rats & 16.0 & $46.8^{*}$ & 21.8 & 8.0 & 7.4 \\
Q79 & B2: & Female rats & 13.1 & 31.1 & $32.1^{*}$ & 17.6 & 6.1 \\
Q80 & B3: & Male mice & 23.7 & 40.1 & $27.9^{*}$ & 3.5 & 4.8 \\
Q81 & B4: & Female mice & $70.5^{*}$ & 18.9 & 4.8 & 0.3 & 5.4 \\
\hline
\end{tabular}

Note. Cell entries are percentages. The classification assigned by the panel of the National Toxicology Program is marked with an * for items Bl to B4.

\begin{tabular}{|c|c|c|c|c|c|c|c|}
\hline & & & $\begin{array}{l}\text { Strongly } \\
\text { disagree }\end{array}$ & Disagree & Agree & $\begin{array}{l}\text { Strongly } \\
\text { agree }\end{array}$ & $\begin{array}{c}\text { Don't know/ } \\
\text { no opinion }\end{array}$ \\
\hline Q82 & B5: & $\begin{array}{l}\text { In general, animal studies of the type } \\
\text { done with Chemical B will permit one } \\
\text { to make reliable judgments of the } \\
\text { likelihood that the chemical is } \\
\text { carcinogenic in humans }\end{array}$ & 2.9 & 37.8 & 52.2 & 1.0 & 6.1 \\
\hline Q83 & B6: & $\begin{array}{l}\text { Based on the data presented above, a } \\
\text { concentration of } 1 \text { ppb of Chemical B } \\
\text { in indoor air is acceptable }\end{array}$ & 5.4 & 22.1 & 38.5 & 8.3 & 25.6 \\
\hline
\end{tabular}

The data are

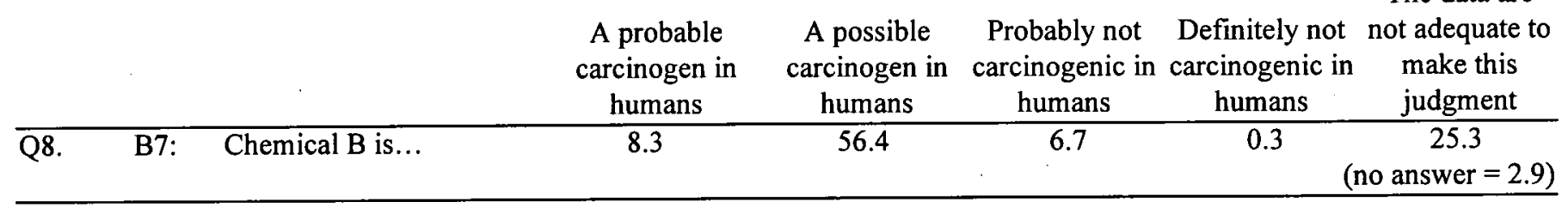


Table 12. Evaluations of Compound $E$

\begin{tabular}{|c|c|c|c|c|c|c|c|c|}
\hline & & & Very low & Low & Moderate & High & $\begin{array}{l}\text { Very } \\
\text { high }\end{array}$ & $\begin{array}{c}\text { Don't know/ } \\
\text { no opinion }\end{array}$ \\
\hline \multirow[t]{2}{*}{$\overline{\mathrm{Q} 92}$} & E1: & $\begin{array}{l}\text { The overall relative toxicity } \\
\text { of Compound } E \text { is: }\end{array}$ & 1.0 & 29.8 & 48.7 & 8.0 & 0.0 & 12.5 \\
\hline & & & $\begin{array}{l}\text { Strongly } \\
\text { disagree }\end{array}$ & Disagree & Agree & $\begin{array}{l}\text { Strongly } \\
\text { agree }\end{array}$ & & $\begin{array}{l}\text { Don't know/ } \\
\text { no opinion }\end{array}$ \\
\hline$\overline{\mathrm{Q} 94}$ & E2: & $\begin{array}{l}\text { The presence of Compound } \\
E \text { in rubber baby bottle } \\
\text { nipples is acceptable }\end{array}$ & 15.7 & 51.6 & 14.4 & 2.6 & & 15.7 \\
\hline
\end{tabular}

Note. Cell entries are percentages. 


\section{Figure Captions}

Figure 1. Health risks to the average exposed citizen of your country.

Figure 2. Health risk perceptions to average exposed citizen: Difference between males and females.

Figure 3. Health risk perceptions to average exposed citizen: Difference between British and European toxicologists.

Figure 4. Health risk perceptions to average exposed citizen: Difference between British and Canadian toxicologists.

Figure 5. Attitudes and opinions: Percent difference in agreement between British and Canadian toxicologists. 


\section{Figure 1}

\section{Health risks to the average exposed citizen of your country}

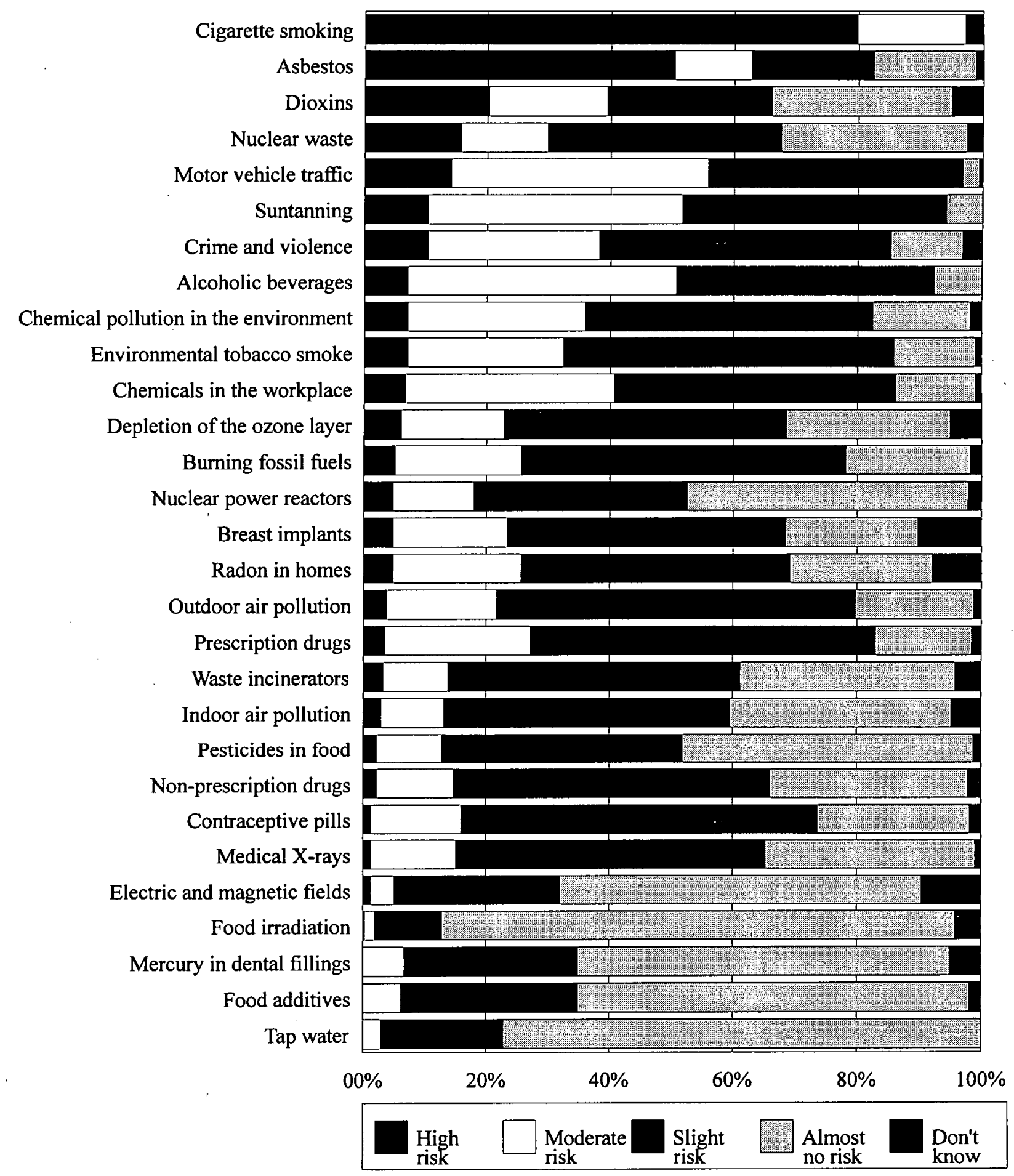




\section{Figure 2}

\section{Health risk perceptions to average exposed citizen}

\section{Difference between males and females}

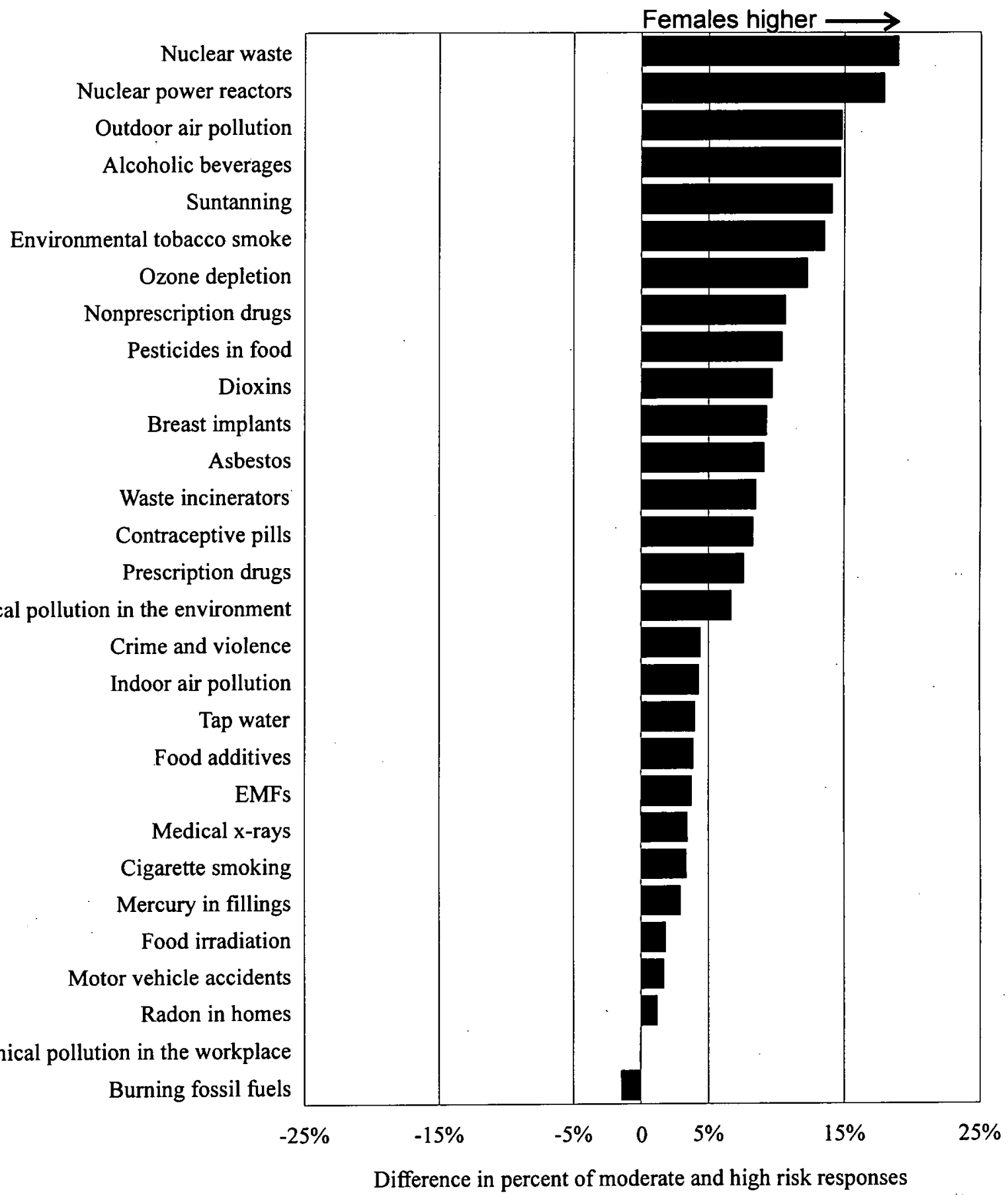

Note: Percent difference is percent female moderate and high risk responses minus percent male moderate and high risk responses. 
Figure 3

Health risk perceptions to average exposed citizen

Difference between British and European toxicologists

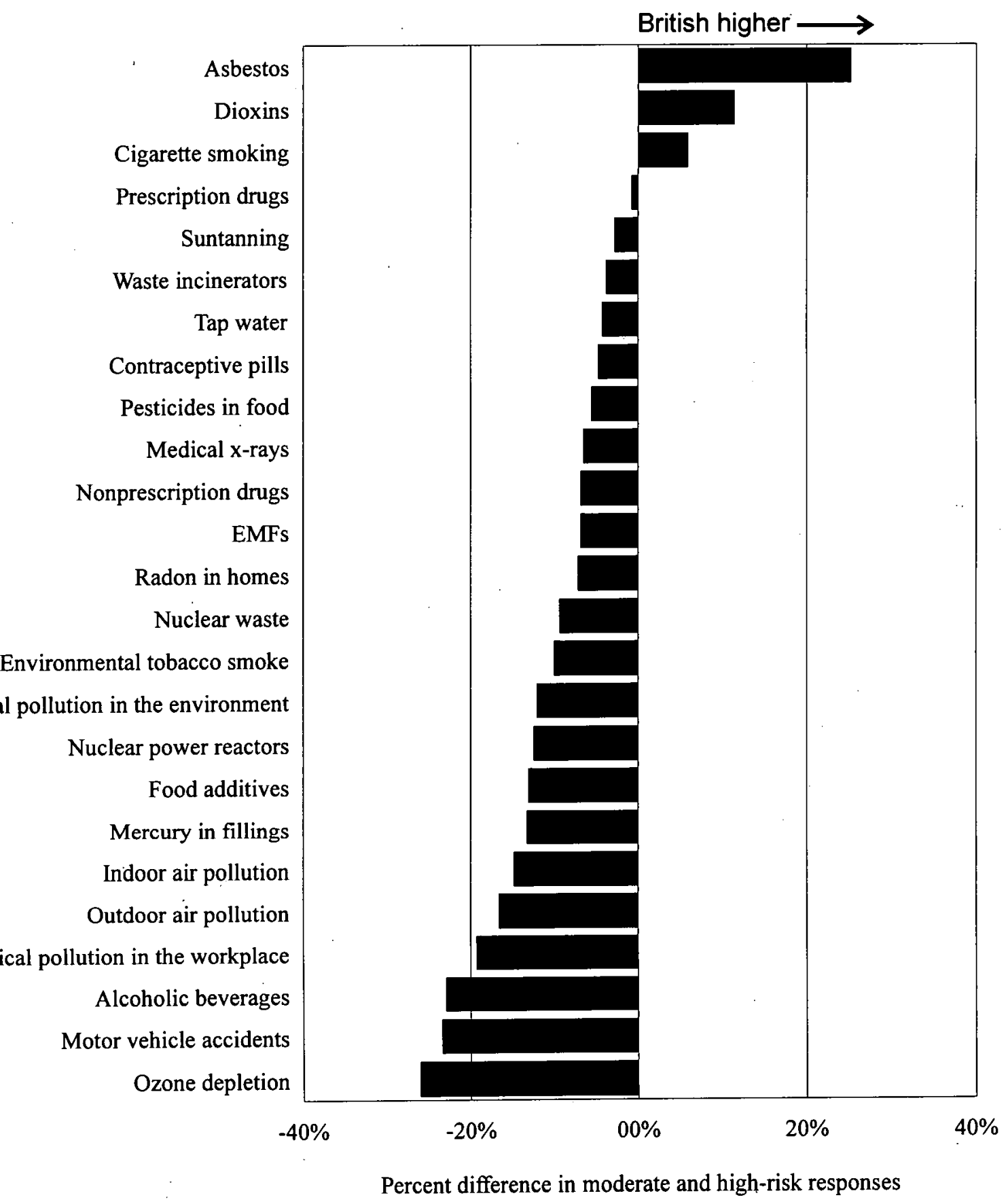

Note: Percent difference is percent British toxicologists moderate and high-risk responses minus percent European toxicologists moderate and high-risk responses. 
Figure 4

Health risk perceptions to average exposed citizen

\section{Difference between British and Canadian toxicologists}

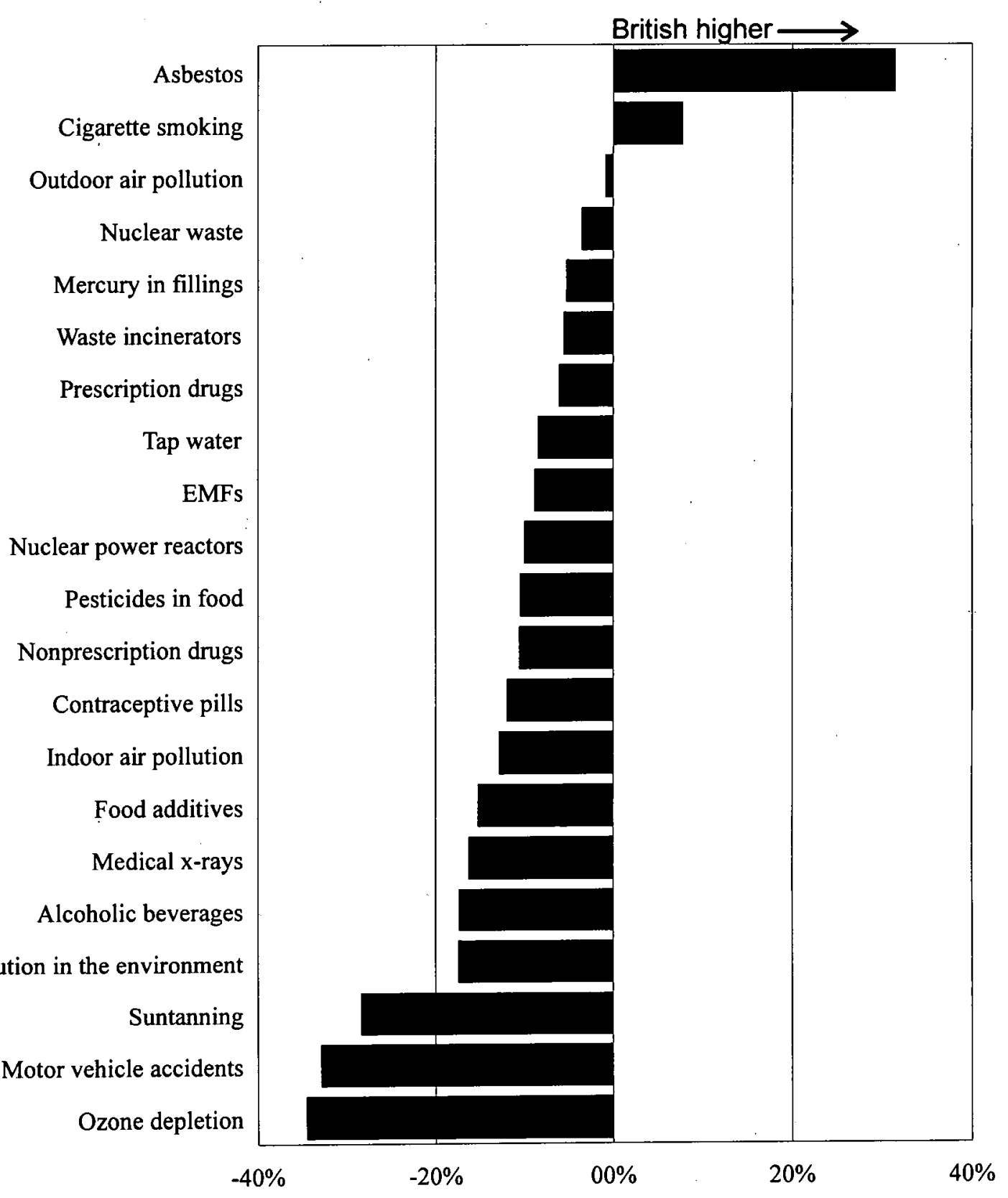

Percent difference in moderate and high-risk responses

Note: Percent difference is percent British toxicologists moderate and high-risk responses minus percent Canadian toxicologists moderate and high-risk responses. 
Figure 5

Attitudes and opinions

Percent difference in agreement between British and Canadian toxicologists

Government has no right to regulate people's personal risk-taking activities such as drinking alcohol, mountain climbing, etc.

Decisions about health risks should be left to the experts

Experts are able to make reasonably accurate quantitative estimates of the health risks from chemicals in the environment

People in positions of authority tend to abuse their power

Chemical risks are sufficiently regulated in this country

If people in this country were treated more equally, we would have fewer problems

If a carcinogen were found in my tap water at levels below regulatory concern, I would not drink the water*

When a risk is very small, it is okay for society to impose that risk on individuals without their consent

I feel that I have very little control over risks to my health

A high technology society is important for improving our health and social well being

If a person is exposed to a chemical that can cause cancer then that person will probably get cancer some day

In a fair system people with more ability should earn more Fruits and vegetables contain natural substances
that can cause cancer

Continued economic growth is necessary to improve our quality of life

There are serious environmental health problems where I live

I try hard to avoid contact with chemicals and chemical products in my daily life

If a scientific study produces evidence that a chemical causes cancer in animals, then we can be reasonably sure that the chemical will cause cancer in humans

The way that an animal reacts to a chemical is a reliable predictor of how a human would react to it

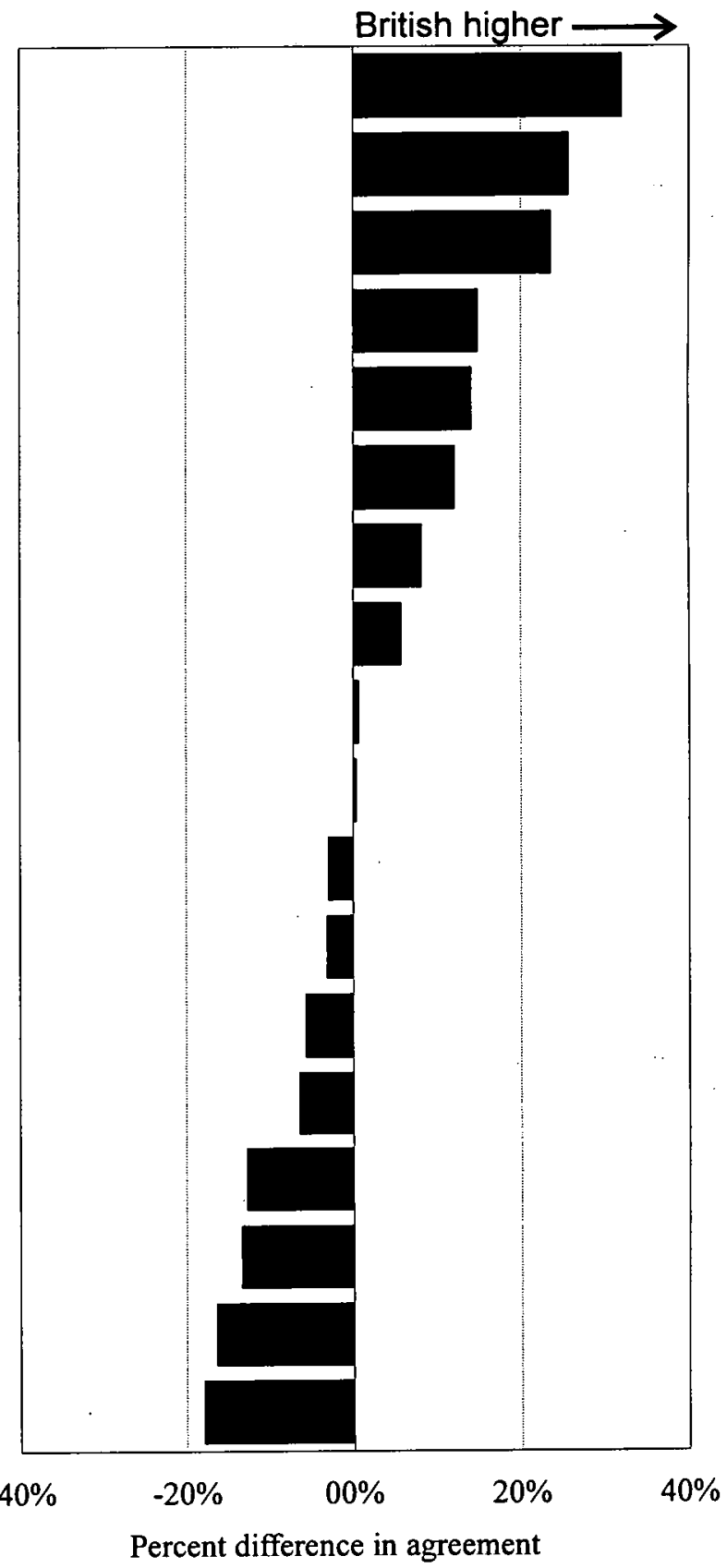

*This text is from the British survey. The Canadian version of this question differed slightly.

Note: Percent difference is percent of British toxicologists agree and strongly agree responses minus percent of Canadian toxicologists agree and strongly agree responses. 